\title{
POUKA O OVOZEMALJSKOM ČISTILIŠTU IZ FATEVIĆEVA ZBORNIKA
}

U Fatevićevu zborniku iz 1617. godine zapisan je moralnopoučni sastav Zarcalo duhovno, prijevod djela Speculum spiritale, čiji je jedan odjeljak posvećen Čistilištu svetoga Patricija. U promišljanju o čistilištu kao »međuprostoru« u vječnosti, tijekom stoljeća došlo se i do ideje o postojanju ovozemaljskoga čistilišta (tu su specifični nazori o povezanosti i međuprožimanju transcendencije i tvarnoga svijeta u Hildegarde iz Bingena), a najpoznatije je takvo mjesto bilo upravo Čistilište sv. Patricija u Irskoj. Ono je bilo opisivano kao cilj pokorničkoga hodočašća, ali i kao mjesto u kojem se duše muče ili (znatno rjeđe) doživljavaju blaženstvo. Kao takvo tema je dvaju hrvatskoglagoljskih tekstova: pripovjednoga teksta (vizije) iz Oxfordskoga zbornika, te teološko-poučnoga odlomka iz Fatevićeva zbornika. Dok je vizija već objavljena i bolje proučena, dotle je odlomak iz Zarcala dosad bio gotovo nezapažen u našoj filologiji. U ovom se radu donosi transliteracija teksta o Čistilištu sv. Patricija iz Fatevićeva zbornika, s osvrtom na njegove stilske značajke - budući da je tekst o irskome pokajničkom prostoru dio većega sastava poučnoga, vjerskoga značaja, to je njegova estetska funkcija svedena na minimum. Pomak od književnoga prema poučnom kontekstu možda je indikator kako je zanimanje publike za vizije kao književna djela do početka 17. stoljeća opalo, ali su takve teme ostale privlačne u ozračju teološke i moralne pouke, budući da je odjeljak o sv. Patriku uklopljen u pouku o ispravnu životu i dobru umiranju. U promatranom se tekstu zrcali povezanost teološke doktrine i pučke pobožnosti.

Ključne riječi: Fatevićev zbornik, hrvatskoglagoljska moralnopoučna proza, vizije, Čistilište sv. Patricija, Hildegarda iz Bingena

\section{UVOD}

Ove se godine navršava 400. obljetnica sastavljanja Fatevićeva zbornika, pa je to prigoda da se iz njegova sadržaja izdvoji dosad u našoj znanosti gotovo nepoznat prijevod teksta o ovozemaljskome čistilištu. Fatevićev zbornik skup je duhovnoga štiva što ga je sastavio Mikula Fatević, kapelan na otočiću 
Ravi u zadarskom arhipelagu (druga pol. 16. st. - prva pol. 17. st.), ${ }^{1}$ pa je rukopis po njemu i nazvan. Danas se čuva u Zagrebu, u Arhivu Hrvatske akademije znanosti i umjetnosti. Dva zapisa popa Mikule Fatevića, a osobito onaj s početka Zrcala, datiraju rukopis u 1617. godinu. Na listu 44r čita se:

Zarcalo duhovno dano vanka po ocu poštovanomu fr(a) Anjelu Milanežu. Ovo tumačene e izvaeno zgor rečenoga libra koi e u štanpi latinskoi ko pripisa iz latinskoga u slovinski počtovani g(ospodi)nb Ivan Žoruliĉ Pažanin a sada po milosti Božijoi ê pop Mikula Fateviĉ buduĉi kapelan na Ravi ispisah isti libar na d.ï. (15.) dan miseca febrara .č.k.ž.ï. (1617.) ${ }^{2}$

Fatevićev zbornik valja sustavno jezično-stilski, tekstološki i žanrovski analizirati; na prvi je pogled razvidno kako je pisan u maniri srednjovjekovnih glagoljskih zbornika koji su sadržavali teološke, propovjedne i nabožnopripovjedne sastave. Dosadašnja su istraživanja, primjerice, pokazala kako je taj zbornik vrijedan izvor za proučavanje korpusa propovijedi sačuvanih u hrvatskoglagoljskoj tradiciji. ${ }^{3}$

Vjekoslav Štefanić piše da čitava knjiga obaseže 80 listova, a na listovima 44-71 zapisan je tekst Zarcalo duhovno (Speculum spiritale) ${ }^{4}$, teološkopoučno djelo lombardskoga teologa fra Anjela Milaneža (Angelo da Milano, Angelus Hallensis, Elli Angelo, Angelo a Mediolano), što ga je bio preveo Ivan Žorulić s Paga, a prepisao Mikula Fatević. ${ }^{5}$ Izraz latinski u navedenu Fatevićevu zapisu može značiti da je predložak bio latinski, ali valja podsjetiti kako su senjski tiskari pod izrazom »latinski« podrazumijevali talijanski jezik (dok je latinski za njih bio »dijački«). ${ }^{6}$ Bit će da je djelo, kako je bilo dostupno

1 Usp. PETROVIĆ 1998: 143.

2 Svi navodi iz Fatevićeva zbornika i drugih hrvatskoglagoljskih tekstova donose se prema izvornicima digitaliziranima na intranetu: https:// izvori.stin.hr (ur. M. Čunčić, A. Magdić, Lj. Mokrović), posjećeno u siječnju i veljači 2017. g. U ovom radu nije konzultirano izdanje zbornika (faksimil i transliteracija) iz 2016. g. što ga je pripremila Grozdana Franov-Živković (FRANOV-ŽIVKOVIĆ 2016).

3 »Utvrđeno je da je Fatevićev zbornik nezaobilazan rukopis kada je riječ o rekonstruiranju nepotpuno sačuvana glagoljskoga Korizmenjaka, jer jedini sadržava gotovo u potpunosti cjelovit prijevod i početak prve korizmene propovijedi.« (RADOŠEVIĆ 2012: 101) i nadalje, rukopis »nije samo važan po čuvanju starijih srednjovjekovnih hrvatskih glagoljskih tekstova, nego i po tome što su nam danas neki od tih tekstova upravo u njemu i sačuvani kao jedini.«(RADOŠEVIĆ 2012: 136).

${ }^{4}$ U znanstvenoj se literaturi izvornik kadšto naziva Speculum spiritale, a kadšto Speculum spirituale.

5 Usp. ŠTEFANIĆ 1970: 57-60.

6 Vidi HERCIGONJA 1975: 430. O vjerojatnosti da je predložak Zrcalu bio talijanski usp. citat Vj. Štefanića koji je preuzet u FRANOV-ŽIVKOVIĆ 2016: 11. 
Žoruliću, bilo napisano na talijanskom jeziku (»Speculum spiritale vite humane per modum dialogi inter magistrem et discipulum. Italice $\left.\ll^{7}\right)$. Fra Angelo da Milano napisao je više djela, od kojih je Speculum spiritale najpoznatije; između 1608. i 1715. g. doživjelo je šest izdanja, a peto je izdanje 1718. g. dospjelo na indeks zabranjenih knjiga. ${ }^{8}$ Djelo je u kratkom vremenu od objavljivanja prevedeno (i prepisano) $\mathrm{u}$ nas.

\section{O OKAJANJU GRIJEHA NA OVOM SVIJETU - PURGATORII OD SVETOGA PATRICIE}

Među raznim dijelovima Zarcala duhovnoga koji tematiziraju usud duša nakon smrti, raj, čistilište i pakao, vještinu dobra umiranja i đavlove napasti u agoniji, nalaze se i priče o dušama umrlih koje se "purgivaû na ovom svitu«. Na njih se nastavlja kraće tumačenje ili pouka o tzv. Čistilištu svetoga Patricija. Taj glagoljski tekst nije identičan viziji o iskustvu pobožnoga viteza Nikule koji je u tom čistilištu okajao svoje grijehe; ona je zapisana u hrvatskoglagoljskom Oxfordskom zborniku iz 15. stoljeća. Dok je potonji tekst svojevrstan spoj svetačke legende (čudesa) i eshatološke vizije (putovanja kroz onostranost), ${ }^{9}$ dotle je mlađi sastav po svojoj namjeni poučan (pastoralan) sastav, dio traktata.

Odlomak iz Fatevićeva zbornika posvećen Čistilištu sv. Patricija glasi ovako (listovi $52 \mathrm{v}-54 \mathrm{v}):^{10}$

Ĵa sam slišal da prgatorii opceniĵ u ednom mistu samom i da se duše purgivaû $i$ jošče u nika druga razlučita mista tako opĉeni esu veĉe prgatoriev i dakle i jistino da i purgatorii od svetoga Patriciê.

(53r) Šte se u liendi od svetoga Patriciê pisana od mnozih pisaniko(v) ${ }^{11}$ a (o)sobitim načinom od Vicenca Belvacense i od svetoga Antona u drugom dilu od negove na puntu edanaestom a na glav .3.ï. $(=18)$ i .1.b. $(=52)$ pokle s(ve)ti Patricii biše obratil svu jižulu od Ibernie na veru Isukrstovu sa svoim pripovidaniem

\footnotetext{
${ }^{7}$ WADDINGUS 1806: 16. Djelo se ne spominje u Grabesovu iscrpnom katalogu latinskih djela koja u naslovu imaju izraz speculum. Usp. GRABES 1982.

${ }^{8}$ Usp. CHIETTINI 1948: 1257.

${ }^{9}$ DÜRRIGL 2016.

${ }^{10}$ Transliteracija teksta provedena je prema načelima za izradu Rječnika crkvenoslavenskoga jezika hrvatske redakcije (Staroslavenski institut, Zagreb): za đerv se rabi znak $\hat{\jmath}$, za šta se rabi $\hat{c}$, za jat se rabi $\hat{e}$, a za ju se rabi $\hat{u}$. Riječi su napisane rastavljeno, ali bez zahvata u izvornu interpunkciju; kratice su razriješene radi lakšega čitanja. Velika su slova napisana kao u izvorniku, osim što smo i vlastita imena ovdje donijeli s velikim početnim slovom radi lakšega praćenja teksta.

${ }^{11}$ Štefanić čita kao pisaniko, ne prepoznajući genitivni oblik (v. ŠTEFANIĆ 1970: 59).
} 
oni lûdi krudeli drugi edva hotiêše verovati drugi život govoreĉi od sudo(v) i muk od pakla i prgatoriê Da on s(ve)ti za neka ono ča s ričami nim biše pripovidal da bi oni ukazali jošĉe u dilu moli vele našega g(ospodi)na zvrhu ovoga s molitvama i žežini ${ }^{12}$ ukazavši mu se paka go(spodi)nь da mu edne knige od jevanjelev s jednim šĉapom i potole nega popela u edno misto dezerto i s rečenim šĉapom desina mu ednu veliku êmu škuru govoreĉi mu da ki koli bi u rečenu êmu ili v studenac ulizal s pravom verom istinim načinom pokaêl se od svoih griho(v) u nem stoeĉi za hip od jednoga dne i ednu noĉ da bi se purgal od svoih muk od negovih griho(v) i pasavši vnutar i vanka iz onoga studenca ne samo videl bi // (53v) mučenie od zalih da i jošĉe vesele od dobrih i odšadši go(spodi)nь osta s(ve)ti Patricii vas vesel i ondika sazida ednu crikvu i postavi ei na stražu kanoniko(v) od svetoga Agustina pridavši kluči priuru za neka niedan ne ulize u rečeni studenac brez lecencie i mnozi potole ulizoše u oni studenac koi svidočahu da esu vidili čuda stvari kako se duše muče od razlučitih mučeni a ke stvari sveti Patricii naredi da sve budu pomnene i pisane u onoi crikvi gdi oni puk videĉi ovo virova predikam od svetoga Patriciê i zato duše ondi se purgivaû za ovo ono misto ${ }^{13}$ bi zvano prgatorii od svetoga Patriciê Vicenc Belvacense govoreĉi od ove ištorie govori da onamo ni priimane od mnozih sveti Anton govori da ako mi govorimo od ove kako nici govore koi stanuû u nih stranah gdi se nahodi ovi studenac ča e da potle da oni ludi esu stali u nom mistu // (54r) za edan mal hip od vrimena kratka u komu uzdrže se one velike muke i travalaniê od hudob i samim načinom i s mišlenem i da paka od onuda vraĉaû se jošče za životi na s(ve)tu kako čine druzi i da za one muke od onoga prgatoriê šatišvivaû nihovim mukam dužne nihovim grihom od ove opinioni govori ovi s(ve)ti ne vidiše naslidovati nici nenadiino Do ovde sveti Anton koi govori jošĉe od ove iste materie u četvrtom dilu od svoe Kušncie na puntu četrnades(e)tom a na glavi .ï. (=10) i .d.ï. (=15) svetoga Bonavintura govoreĉi od ovoga u četvartom na razlučenu .g. (=4) ova poslidna od prvoga dila govori s(ve)ti Patricii da e on jimal od Boga da edan negov priêtel biše osuen na edno misto na zemli i da pokle govorenim načinom bi učinom učineno ono ča se govori da ondi bude prgatorii i ovo govori zgoru rečeni $\mathrm{s}(\mathrm{ve}) \mathrm{ti}$ koê je opinijon vele mi e draga i jošĉe da druga od zgora ne bude dalečna od jistine // (54v) začto kako esmo rekli prgatorii ne govori narednim načinom nahodi se u veĉe mesti i ovo dosti budi za sada.

\section{Talijanski predložak iz pera fra Angela da Milano pak tumači:}

Hò inteso Maestro, che il Purgatorio commune è un luogo solo, \& che l'anime si purgano anco, in alcuni altri diuersi luoghi. Si che in somma sono più Purgatorii. E dunque anco il vero, che vi sia il Purgatorio di San Patritio? Di gratia dichiaratemi questo.

MAESTRO. Si legge nella legenda di S. Patritio, scritta da molti Scrittori, \& specialmente da Vicenzo Beluacense, \& da sant'Antonino nella 2. par. della suo Somma Historiale, al tit. 11. cap. 18 §2. qual dice. Doppo che S. Patritio hebbe

12 Žežin(ati) $=$ 'post(iti)'.

${ }^{13}$ Marginalni zapis: Prgat(o)rii od s(ve)t(o)ga Patriciê kada poči. 
conuertito tutta l'isola d'Hibernia, alla fede di Christo, con il suo predicare: Quella gente ferina, \& indomita, appena uoluea credere l'altra uita parlando delli giudicii, $\&$ pene dell'Inferno, \& Purgatorio; Ma il Santo, acciò che quello, che con parole gli haueua predicato, prouassero anco il fatti. Prego assai Nostro Signore sopra questo, con Orationi, \& Digiuni; apparendogli poi alla fine il Signore, gli donò un libro de gli Euangeli con un bastone. Et doppo lo condusse in un luogo deserto, \& con il detto bastone, gli dissegnò una grande // (str. 116) fossa oscura, dicendogli, che chiunque in detta fossa, ò pozzo entrasse, con vera fede, veramente pentito de suoi errori, iui stando per spatio d'un giorno, \& una notte, si purgarebbe da tutte pene delli suoi peccati. E passando dentro, \& fuori di quello pozzo non solo uedrebbe gli tormenti delli cattiui: ma ancora gli gaudii delli buoni. Disparendo poi il Signore, San Patritio restò tutto allegro, \& iui edificò una Chiesa, \& gli posse alla custodia i Canonici di Sant'Agostino, consegnando le chiaui di detto pozzo, al Priore, acciò niuno uentrasse senza licenza di quello. molti dopò entrono in quel pozzo, li quali testificauano d'hauer uedute assai cose, come anime tormentate da diuersi tormenti: La qual cose, San Patritio ordinò, che tutte fossero notate, \& scritte, in quella Chiesa. Onde quel Popolo, uedendo questo: credette alle prediche di San Patritio, \& perche l'anime iui si purgano: per questo, quel luogo fu chiamato Purgatorio di San Patritio. Vicenzo Beluacense, parlando di questa historia, dice, che non è riceuuta da molti. Santo Antonino dice, che se noi diciamo di questa, come alcuni dicono, quali habitano in quelle parti, doue si troua que//(str. 117)sto pozzo, cioè che doppo, che quelli huomini son stati in quel luogo, per un certo spatio di tempo breue, nel qual sostengono coloro gran pene, \& trauagli dalli Demonii, solamente con l'imaginatiua, $\&$ che poi di là tornano ancora à uiuere al mondo, come fanno gli altri, \& che per quelle pene di quel Purgatorio sodisfano alle lor pene debite alli suoi peccati: da questa opinione (dice questo Santo) non si uede seguitar alcun'inconueniente. Sin quì Sant'Antonino il qual tratta anco di questa istessa materia, nella quarta parte della sua somma di conscienza, al titolo 14, capit. 10 §8. San Bonauentura parladno di questo, nel quarto, alla distin. 20. questione ultima della prima parte, dice che San Patritio ottene da Iddio, ch'un certo suo amico fosse punito in un certo luogo in terra, \& che doppo fauolosamente, sia nato, quello, che si dice che iui sia il Purgatorio, \& questo dice il predetto Santo. La quai opinione affar mi piace, anchor che l'altra di sopra, non sia lontana dal uero, perche (come habbiamo detto) il Purgatorio (non parlando ordinariamente) si ritroua in più luoghi. E questo basti per adesso. ${ }^{14}$

\section{3. »SMJEŠTAJ« ČISTILIŠTA}

U zrelom je srednjovjekovlju cogitatio mortis više pozornosti usmjeravala na neki čistilišni »prostor« i »stanje« u kojemu bi bile duše onih koji nisu

\footnotetext{
${ }^{14}$ Talijanski je tekst citiran prema izdanju iz 1601. godine pod naslovom SPECCHIO SPIRITVALE Del principio, e fine della Vita humana [...] Per il R. P. F. Angelo Elli da Milano, Minor Osseruante [...] In Treuiso, Appresso Fabritio Zanetti, M. DCI.
} 
blaženi, ali nisu ni okorjeli grešnici predodređeni za vječne muke. To je bio svojevrstan odgovor na reduktivni dualizam raj - pakao u razvoju promišljanja o transcendenciji. Od Augustina do Tome Akvinskoga te su se predodžbe mijenjale i postupno oblikovale, a u okviru takva promišljanja pojavile su se i ideje o mogućnosti očišćenja za ovoga, vremenitog života, tu, na zemlji - otuda misao da su neki zemljopisni prostori »obdareni« čistilišnim moćima. Vjerojatno najpoznatije takvo mjesto u povijesti Zapada bilo je tzv. Čistilište svetoga Patricija, špilja na sjeveru Irske.

Špilje su oduvijek fascinirale ljude, bilo kao zastrašujuća mjesta, bilo kao zakloni ili sveta mjesta. Shvaćanja, vjerovanja i nauk o čistilištu oblikovali su se postupno. Najiscrpniji prikaz »povijesti« doktrine o čistilištu jest onaj iz pera Jacquesa Le Goffa, premda mu neki povjesničari i teolozi spočitavaju suviše mehanicistički i strukturalistički pristup tematici. Nije neobično da je u popularnoj pobožnosti, koja je od srednjega vijeka hranjena više slikama muka nego li obećanjima radosti, bila privlačna mogućnost okajanja grijeha već »ovdje i sada«, za života, i smanjivanja patnje nakon smrti. Često se kao (književna) djela koja su najviše proširila poimanje čistilišta navode Gast of Gy, priča viteza Oweina o boravku u Čistilištu sv. Patricija i Tundalova vizija. ${ }^{15}$ Općenito se od kasnoga srednjeg vijeka poučavalo i propovijedalo da pokoru valja činiti već za života; brojni su egzempli, i u njima sadržane male vizije i ukazanja, tematizirali i pojačavali tu poruku. ${ }^{16}$ Glavna je namjera takvih tekstova, bilo poučnih bilo onih s kakvim-takvim književnim pretenzijama, poticanje vjernika na ispravan način života, na izbjegavanje grijeha i na pokajanje. ${ }^{17} \mathrm{I}$ u duhovnome perivoju Vartal nalazi se poziv na strpljivo podnošenje bolesti, jer svako trpljenje za života donosi neku nagradu ili zadovoljštinu u vječnosti: »Nemoć telesna ima se podnest(i) dobrovolno, jer nas one uklanjaju od muk prišasnih. Bog ne sudi dvakrat jedan grih. I zato svakomu grišniku ima drago bi(ti) ko je sagrišio, znajući da ima imati pokoru za nje ovdi, ali tamo u purgatoriju. ${ }^{18}$ Ovdje je riječ o nemoći, dakle o bolesti, ali i ona se veže uz tjelesnu neugodu, patnju i trpljenje. To sve nudi mogućnost

$\overline{15}$ Usp. FOSTER 2004.

$16 »[\ldots]$ penance for sins was far more easily done in this life than after death.« (DUFFY 1992: 342)

17 »The miseries of Purgatory, then, like the physical horrors of the process of death itself, were evoked not to curdle the blood and opress the spirit, but to stir the living to present action.« (DUFFY 1992: 343)

${ }^{18}$ Cit. prema izdanju LUCIĆ 1990: 265. Tako i Hildegarda iz Bingena u Liber vitae meritorum sustavno preporučuje vrstu i težinu pokore za pojedine grijehe, kako bi se umanjila kazna u transcendenciji - u nje ta pouka dolazi od Vječnoga Svjetla, stoga na koncu uvijek kaže: $» \mathrm{Hec}$ autem de penitentium animabus purgandis et saluandis dicta sunt, et fidelia sunt.«Usp. CARLEVARIS 1995: 163. 
okajanja i očišćenja, dakle nadu već za ovoga života - kako je koncem 14. st. zapisala mističarka i pustinjakinja Julian iz Norwicha, »peyne is passand «. ${ }^{19}$ Purgatorij je u Čistilištu sv. Patricija »premješten« u ovozemaljsku stvarnost, s ove strane smrti. Ono uključuje i tjelesne patnje kako bi se duša očistila; koliko li će Bogu biti milija žrtva koju je grešnik svojevoljno, dragovoljno na sebe preuzeo silaskom u strašno čistilište!

Tema je čistilišnoga prostora već i prije službeno prihvaćene teološke doktrine o čistilištu bila privlačna, pa se takvi prostori - bolje rečeno, takva stanja - opisuju u latinskoj i raznim vernakularnim književnostima. O čistilištu se u nabožnim književnim djelima pripovijeda i prije 12. stoljeća - primjerice, već se među čudesima sv. Tekle i sv. Perpetue spominje kako su njihovim molitvama neke duše bile izbavljene od paklenih muka. ${ }^{20}$ Brojna su djela (a napose valja istaknuti Dijaloge Grgura Velikoga) koja spominju neko čistilišno stanje u kojemu duše čekaju Sudnji dan i svoje uskrsnuće; naime, duše osuđene na paklene muke neće uskrsnuti, dok oni koji nisu sasvim zli imaju nadu ulaska u vječnu radost. Dotad, kako primjerice piše Ælfric (pol. 10. - poč. 11. st.), svaka duša po svojim zaslugama doživljava ugodu ili trpljenje: »and heo gefret softnysse oððe sarnysse «. ${ }^{21}$ Slično se čita već u Pavlovoj viziji u Oxfordskom zborniku iz 15. stoljeća, kada se blaženoj duši kaže: »o duše blagaê poznavai svoe telo s kim' imaši stati« (2b), dok se zla duša ima »zaklopitb û v' tam'nici adskoi« (3d). U pučkoj se pobožnosti čistilište dovodi u vezu s paklom, barem po težini i vrsti muka koje duše moraju trpjeti; o tome pripovijedaju mnoge vizije i ukazanja (npr. Tundalova/Dundulova vizija) i egzempla koja spominju npr. Petrus Damiani, Elisabeth von Schönau, Caesarius von Heisterbach ${ }^{22}$ i mnogi drugi. Muke koje nisu paklene odnosno vječne, izrijekom spominje i hrvatskoglagoljska inačica Dundulove/Tundalove vizije u Petrisovu zborniku: "zato oĉe ima tr'pêti prgatorie vsaki dan' « ili »i zato imaû nikoliko lêtb [...] trpeĉe a potom' budu postavleni na vê'čno vesel'e «. ${ }^{23}$

Promatrajući širi fenomen Čistilišta sv. Patricija - i kao realnoga prostora, i kao hodočasničkoga/pokajničkoga središta, ${ }^{24}$ i kao književne teme - primjetno je da starija žitija toga sveca ne spominju nikakvih čudesa koja je činio u

\footnotetext{
${ }^{19}$ Usp. THIÉBAUX 1994: 448.

${ }^{20}$ Usp. GARDINER (ur.) 1989.

${ }^{21}$ Cit. prema GATCH 1991: 198. Takvi se nazori iščitavaju iz raznorodnih tekstova napisanih diljem Europe, na brojnim jezicima.

${ }^{22}$ Ideju o postojanju većega broja čistilišta Caesarius iznosi u svome iznimno opsežnom djelu Dialogus miraculorum iz ranoga 13. stoljeća.

${ }^{23}$ Usp. transkripciju teksta u DÜRRIGL 2013: 213.

${ }^{24}$ Čistilište eo ipso predstavlja kretanje, mijenu, peregrinatio duše prema oslobođenju.
} 
smislu otvaranja čistilišne provalije, kako bi potaknuo tvrdokorne pogane da konačno povjeruju u Krista. ${ }^{25}$ Prvi se put to čistilište, odnosno taj geografski prostor i hodočašća u nj s ciljem okajanja grijeha, spominju u Vita s. Patritii Jocelyna de Furnessa (napisanoj između 1180. i 1183. g.), kao i u Topographia Gilbertusa Cambrensisa (između 1185. i 1187. g.). ${ }^{26}$ Vizija pak poznata pod naslovom Čistilište svetoga Patricija (Purgatorium sancti Patricii) nastala je koncem 12. stoljeća na latinskom jeziku; iz istoga razdoblja potječe Tractatus de Purgatorio S. Patritii. ${ }^{27}$ Dosadašnje tekstološke i književnopovijesne analize nisu dale nedvojben odgovor na pitanje točnoga vremena nastanka izvornika niti autorstva djela Purgatorium sancti Patricii. U prologu djela spominje se frater H. monachorum de Saltereia ${ }^{28}$ koji je oko 1189. godine zapisao priču pokajnika viteza Oenusa (Owen, Owain, Eogan) o njegovu putovanju u čistilište sv. Patricija na sjeveru Irske. ${ }^{29}$ Upravo vizija viteza Oweina i djelo Tundalova vizija vrhunac su književnosti putovanja kroz onostrano. Ta književna tematika od 12. stoljeća dalje doživljava suton, fabula se krati, opisi su znatno manje dramatični i iscrpni, a vizije onostranosti većinom ulaze u egzemple. ${ }^{30}$

Pripovijest o silasku viteza Oweina postala je vrlo popularna i proširila se velikim dijelom Europe; već u 13. stoljeću ulazi u najpoznatiju kompilaciju svetačkih legendi i čudesa, u Legenda sanctorum Jacobusa da Voragine. ${ }^{31} \mathrm{~S}$

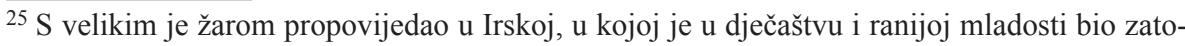
čenikom. Detalji njegova života i misionarskoga djelovanja u Irskoj u drugoj polovici 5. stoljeća ne daju se sa sigurnošću utvrditi, ali je nedvojbeno da se posvetio evangeliziranju pogana i u najudaljenijim područjima Irske, a svoja je iskustva i zapisao. Usp. CRÓINÍN 1998: 1791-1792. Znano je da ga je papa Celestin bio poslao u Irsku, tradicionalno se kao godina njegova dolaska bilježi 432. Predaja o njegovim čudesima, npr. o protjerivanju reptila, posjetu čistilištu i tumačenje Sv. Trojstva pomoću djeteline znatno se proširila, ali o tome nema povijesnih podataka - a neki su od tih legendarnih elemenata i kasnijega postanja. Od 7. stoljeća kult mu se proširio i na europski kontinent, a priča o njegovu čudu s čistilištem nastaje tek u 12. stoljeću i živi, barem na neki način, do danas.

${ }^{26}$ Usp. LE GOFF 1984: 234-235, sa zanimljivim popisom još uvijek relevantne starije stručne literature.

${ }^{27}$ Valja i opet primijetiti kako »termini« u naslovima ne upućuju na žanrovsku pripadnost dotičnih tekstova.

${ }^{28}$ Riječ je o mjestu Saltrey (Sautry) u Engleskoj.

${ }^{29}$ Usp. SPILLING 1975: 226-230. Budući da je vitez onamo putovao oko 1153. godine, raspon od tridesetak godina između (prvoga) usmenog izvješća i pisane verzije omogućio je zasigurno znatno književno ukrašavanje, kao i usustavljivanje pripovjedne građe kroz razne "postaje« na putu očišćenja.

${ }^{30}$ Usp. DINZELBACHER 1991: 30-31; DÜRRIGL 2016: 19-20.

${ }^{31}$ Usp. EASTING 1986. Dakako, bilo je i drugih pokajnika koji su svoje doživljaje u čistilištu dali zapisati, sve dok koncem 15. stoljeća dotična špilja nije zatrpana. Usp. hrvatski prijevod legende u JACOBUS da VORAGINE 2014: 215-218. 
tom se latinskom verzijom, koja uz čudo svetoga Patrika veže iskustvo pobožnoga Nikole koji je sišao u čistilište i okajao svoje grijehe, podudara dijelom i hrvatskoglagoljska verzija legende-vizije, zapisana kao Ot'svetago Patriciê u Oxfordskom zborniku iz 15. stoljeća. ${ }^{32}$ Upravo je taj književni »bestseler«, po Le Goffovu mišljenju, imao presudnu ulogu u širenju doktrine o čistilištu od 12. stoljeća dalje. ${ }^{33}$

Međutim, za širenje (rekla bih, i za produbljavanje) učenja o čistilištu važnu - a dosad u stručnoj literaturi manje zapaženu - ulogu imala su djela mističarke, književnice i skladateljice sv. Hildegarde iz Bingena (1098. - 1179.), napose Liber vitae meritorum. Ona je smatrala da čovjek nije samo stvorenje, nego je Božji sustvaratelj, operarius koji u povijesti spasenja ima važne zadaće. Svijet više nije samo dolina suza, već početak (Le Goff duhovito piše »šegrtovanje « ${ }^{34}$ ) uspona prema Bogu, čovječanstvo ima aktivnu ulogu u Božjem planu stvaranja.

U nastojanju prevladavanja reduktivnoga dualizma pakao - raj, Crkva je u zrelom srednjovjekovlju (a na tragu sv. Augustina i drugih teologa) ${ }^{35}$ počela razrađivati čistilište kao zaseban lokus i stanje. Ono ima samo jedna vrata - vrata prema Raju. U viziji Ot'svetago Patriciê čistilište je »infernalizirano« (Le Goffov izraz) jer je naglasak stavljen na opis muka, trpljenja i strahova što ih duša/pokajnik mora proći - no ipak, čistilište je uvijek nada, otvoren put u blaženstvo i vječno svjetlo nakon okajanih grijeha. Na tome putu mogu pomoći i živi: moliti za umrle, postiti za njih i davati milostinju. ${ }^{36}$ Čistilište sv. Patricija kao locus spominje se i u poučnim djelima, npr. u Historia orientalis J. de Vitryja, Speculum historiale V. de Beauvaisa, ${ }^{37}$ Image du monde G. de Metza (sva djela iz 12. stoljeća); spominje ga i sv. Bonaventura u svo-

32 Usp. izdanja u IVŠIĆ 1948. i DÜRRIGL 2013: 154-155 i 219-223; djelomično izdanje u ŠTEFANIĆ 1969: 220-222.

${ }^{33}$ Usp. LE GOFF 1984: 239.

${ }^{34}$ Usp. LE GOFF 1988: 68. On nastavlja: »Purgatory is a part of the interiorization of religious feeling that, from intention to contrition, demands an internal conversion of the sinner, rather than external acts." (LE GOFF 1988: 76).

${ }^{35}$ Usp. DÜRRIGL 2016: 92-95.

${ }^{36}$ Hildegardinim riječima: „Sed et animabus que in obliuione non sunt, sed que in memoria superne beatitudinis existunt, orationes et elemosyne ac alii sanctitatis labores uiuentium succurrunt, et ipsis remedium salutifere ereptionis afferunt, dum in penis purgationum sunt.« (CARLEVARIS 1995: 257-258); nadalje: »Sed cum homo per donum Spiritus sancti aliquos labores $[\ldots]$ pro requie defunctorum sibi iuste et conuenienter imposuerit, Deus. afflictionem illius digne et iuste suscipit [...] Hic autem de penitentium animabus purgandis et saluandis dicta sunt, et fidelia sunt; et fidelis his attendat, et ea in memoriam bone scientie componat.« (CARLEVARIS 1995: 258-259).

${ }^{37} \mathrm{Na}$ to se djelo, očito, poziva autor Zarcala. 
jim komentarima na Sententiae P. Lombardusa. ${ }^{38}$ Prvotna pripovijest o silasku pokajnika u čistilište i njegovim doživljajima vjerojatno je bila namijenjena redovnicima; no, zarana se proširila i među puk, zahvaljujući i propovjednicima koji su te doživljaje uključivali u pouku i poticaj (kadšto upravo u zastrašivanje) na ispravljanje života i odricanje od zla.

Fatevićev poučni tekst, kao i njegov predložak, nadovezuje se na uvodno poglavlje iz Legenda aurea, u kojem se pripovijeda o Patrikovu čudu - no vizionarskoga dijela, s mnoštvom osjećaja i dramatičnih scena o putovanju viteza Nikule i o njegovim mukama u glagoljskom tekstu s početka 17. stoljeća nema. Oba se teksta, i vizija i poučni tekst, otvaraju svojevrsnom tvrdnjom na koju se nadograđuje daljnja građa. Vizija Ot' svetago Patriciê iz Oxfordskoga zbornika kaže »Nahaêmo da nikim' dušam' dana e(stь) navlaĉna prgatoriê« (46d), a teološki se tekst u Fatevićevu zborniku nastavlja na već iznesene tvrdnje i pouke vezane uz čistilište i kazne za grešnike nakon njihove smrti. Nadalje, vizija na početku ima i kraći pripovjedni (»legendarni«) uvod koji funkcionira kao postavljanje okvira za razumijevanje cjeline - to je ishodišna pouka o postojanju ovostranoga čistilišta u kojem se događaju čudesa zahvaljujući zahvatu sv. Patrika: „zač' on' ot Boga isprosi nikim' lûdem' nь sem' s(vê)ti prgatoriû« (46d). Očišćenje nije dozvoljeno svima, a neki se iz te jame nisu nikada vratili. Zatim slijedi legendarni uvod o samom činu kojim je sv. Patrik otvorio čistilišnu provaliju pred okorjelim poganima (»nepokor'ni i nebogoboini lûdi« (46d)) čime je otvorio put ne samo njihovu pokrštavanju, već i omogućio pročišćenje hodočasnika od grijeha. U toj kratkoj preambuli čudo čini sam sv. Patrik štapom, pa se otvara »propast' velmi čud'no velika i bi êvleno blaženomu Patriciû da tu e(stь) v' onoi zem'li prgatoriê« (47a). Taj legendarni uvod sačuvan je dijelom u Fatevićevu tekstu (odnosno u njegovu predlošku); no u njemu sam Isus otvara usta provalije, a Patriku daje i knjigu evanđelja. Zatim u viziji (i u Legenda aurea) slijedi Nikulin doživljaj s opisima muka i čistilišnih prostora koje vitez gleda i doživljava, a taj je dio jedan od najuspjelijih eshatoloških tekstova naše glagoljske knjige. Emotivni vrhunac strave koju vitez proživljava iskazan je ovako: »i ne mogaše ûre tr'piti te d'êvle strahote I paki nega duša ta nim tresiše videĉi toliku strahotu i veliku silu d'êvlov' i bižaše po vsih' udih' nega hoteĉi se skriti« (47b). ${ }^{39}$

S druge strane, u poučnome se traktatu u Fatevićevu zborniku malo toga doznaje o onome što se hodočasnicima-pokajnicima u Čistilištu sv. Patricija događa; navedena su tek $» j$ jednorečenična« egzempla (»mnozi potole ulizoše v oni studenac koi svidočahu da esu vidili čuda stvari«, »edan negov priêtel biše

${ }^{38}$ Usp. LE GOFF 1984: 243-244.

${ }^{39}$ Usp. izdanje IVŠIĆ 1948: 113-118. 
osuen«) kojima se potvrđuje mogućnost pokajanja za života. To jesu svidočastva, ali se težina ili naglasak u poučnom, pastoralnom tekstu stavlja na crkvene autoritete (sv. Antonin, sv. Bonaventura) i na povijesna djela. Tu se izrijekom spominje da neki ljudi vide/gledaju muke i rajske radosti, ali ne spominje se na koji ih način oni (možda) doživljavaju. S obzirom na datum sastavljanja teksta, kao i činjenicu da se radi o poučnome djelu, takvi detalji vjerojatno su namjerno izostavljeni. Tekstovi u Zarcalu duhovnom većim se dijelom dotiču čistilišta, vjerojatno i stoga što se u 17. stoljeću živo raspravljalo o postojanju čistilišta, što su pak teolozi reformacije odbijali. Na kraju vizije nalazi se potvrda factum est; ono što je vitezu-pokajniku obećano, ostvarilo se: »Nikula [...] uspê o Gospodê i bi nega duša nesena na raisku radost' " (48b). Poučni tekst naprotiv kao da stavlja točku na razgovor bez zauzimanja određenoga stava: »začto kako esmo rekli prgatorii ne govori narednim načinom nahodi se u veĉe mesti i ovo dosti budi za sada.« Tako fra Angelo - a s njim Žorulić i Fatević - nastavlja niz onih koji promišljahu o postojanju nekoliko čistilišnih prostora ili stanja.

\section{ZNAČAJKE STILA}

Stil je poučnoga teksta jednostavan, bez ukrasa, prevoditelj teži što vjernije prenijeti izvornik jer je naglasak na pouci (koja mora biti teološki ispravna). U jeziku se razabiru leksički talijanizmi, npr. satišvivaju, opinijon, lecencie, travalaniê, pasavši, krudeli, dezerto, te sintaktički talijanizam za neka niedan ne ulize. Od figura zastupljen je poliptoton Vicenc Belvacense govoreĉi od ove ištorie govori, ${ }^{40}$ paregmenon učinom učineno te homonimi: za edan mal hip od vrimena kratka; muka i travalaniê; êmu ili v studenac. Prisutne su tek dvije antiteze vnutar $i$ vanka i mučenie od zalih da $i \hat{j}$ ošče vesele od dobrih. Valja ipak istaknuti dva termina koja se koriste, a to su liendi i ištorie - dakle dva su izvora na koja se autor traktata (i njegov prevoditelj, pa zatim i Fatević kao prepisivač) poziva, od kojih je jedan »književni« tekst (lienda, legenda o sv. Patriku), a drugi se može shvatiti i kao "povijesni« i »pri-povijesni« (ištoriê).

Slikovitost i »konkretni« detalji opisa mučenja (ali i ljepote) koji se u Čistilištu sv. Patricija doživljavaju zapisani su u viziji; nasuprot tomu, poučni sastav nije adekvatan prijenosnik takvih sadržaja - pisac se (i prevoditelj) zadržava na spominjanju činjenica »da za one muke od onoga prgatoriê šatišivaû nihovim mukam dužne nihovim grihom«.

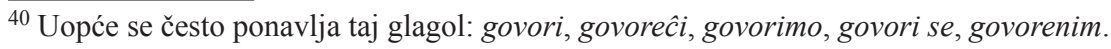


Emocije su u poučnom tekstu iz Fatevićeva zbornika svedene na minimum, za razliku od spomenute eshatološke vizije - međutim, i ovdje se barem ovlaš spominju oni detalji koji u primatelja mogu izazvati emotivnu reakciju. Kao što je velik broj srednjovjekovnih autoriteta, od Augustina do Anselma Canterburyskoga, isticao osjećaje, a osobito strah kao najučinkovitije sredstvo za poticanje promišljanja i (promjene) djelovanja, tako i suvremena neuroznanost dokazuje kognitivnu vrijednost emocija. ${ }^{41}$ Svako dramatično zbivanje - u ovom slučaju, prolazak kroz čistilište i gledanje muka - pokreće u prvi mah nesvjesnu osjećajnu reakciju, a kasnijom »obradom《 doživljaja sintetizira se pozornost, shvaćanje i ponašanje. Nabožna književnost, napose ovakva egzemplarna, a može se kazati i adhortativna djela, potvrđuju da »emocije pretvaraju nagone u socijalne obveze i moralnost, osjećaje povode u poštovanje, a bol u savjest. « ${ }^{42}$ Osim toga, na pamćenje najsnažnije djeluje upravo afekt. Iz brojnih je srednjovjekovnih izvora razvidno kako je tadašnja (široka) pobožnost bila osjećajna; to možda najjasnije dolazi do izraza u vizijama - premda fikcionalna djela, ona kao svaka »angažirana« književnost zrcale tu činjenicu. Dakako, budući da je riječ o poučnom tekstu, valjalo se suzdržavati od pretjerano podrobnih ili dramatičnih opisa. ${ }^{43}$

Oblik dijaloga u kojemu je Zarcalo pisano omogućuje kretanje kroz (zadani) sadržaj, osobito uvođenje novih tema i zatvaranje pojedinih cjelina/odsječaka. Tako se kraći traktati povezuju u poučni lanac, povezan temom sudbine duše nakon smrti, te elementima ars bene moriendi. S druge strane, traktati su, u srednjovjekovnoj maniri, obogaćeni egzemplima i anegdotalnim elementima, kako bi se oprimjerilo ili potvrdilo ono o čemu se govori, ono što se tvrdi; nastojanje oko dramatizacije ili oživljavanja teme manje se razaznaje jer nedostaje slikovitosti, pa i maštovitosti. U tekstu se nalaze i citati, ali i parafraze, upravo reminiscencije na djela teoloških autoriteta, a katkad se ti autoriteti tek ovlaš spominju, vjerojatno s pretpostavkom da čitatelj (već) poznaje te autore i njihova djela (npr. »(o)sobitim načinom od Vicenca Belvacense«). Specifična međuigra detaljnoga citiranja izvora i ovlašnoga spominjanja u prvi mah

$\overline{41} »$ Pre-modern psychologies recognized the emotional basis of remembering. [...] the term affectus included all kinds of emotional reactions. «(CARRUTHERS 1998: 14). Rezultati istraživanja provedenih u 21. stoljeću ukazuju na »pozitivnu ulogu emocija u donošenju odluka. Emocionalna pobuđenost ima snažnu dominaciju nad kognitivnim (mentalnim) procesima.« (GREGUREK 2011: 193). Dakako, valjalo je paziti da strah (kao dar Duha Svetoga) kod grešnika ne prijeđe u otupljelost, torpor, kako je primijetila već sv. Hildegarda.

42 GREGUREK 2011: 193.

${ }^{43}$ Usp. i DELIMO 1986: 606-608. Za ovakav tekst ne bi bio prikladan (aptus) živ opis vidiočeva straha pred mukama kao što se čita u Oxfordskom zborniku: »nega duša ta nim' tresiše videĉi toliku strahotu [...] i bižaše po vsih' udih' nega hoteĉi se skriti gdi bi ne vidila vraž'e strahote« $(47 b)$. 
začuđuje - no razvidno je da je naglasak na citiranoj pouci, a nastoji se izbjegavati ponavljanje. Prvotni je adresat djela bio kler; odgovori, odnosno kraći ili nešto duži traktati o pojedinim pitanjima oblikom i sadržajem kao da su smješteni između skolastičkoga nastojanja oko promišljanja problema, te redovničke tradicije navođenja autoriteta i lectio. ${ }^{44}$ Autor se opredijelio u većoj mjeri za parafraze nego li na vlastitu interpretaciju bilo pojedinoga pitanja/ problema, bilo izvora na koje se poziva. Ne prepoznaje se analitički pristup - a to vrijedi za cjelinu Zarcala, ne samo za tekst o zemaljskome čistilištu - a nedostaje originalno promišljanje, tako da se stječe dojam da je autor takav postupak odabrao imajući u vidu publiku za koju piše. Naime, to ne bijahu učenjaci ili teolozi upućeni u finese, već redovnička zajednica (pomladak?), a kasnije i neka šira publika za neka od pitanja koja su u Zarcalu dotaknuta. ${ }^{45}$

Na početku teksta čita se da je svetac »sa svoim pripovidaniem《 obraćao stanovnike Irske - propovijedanje nerijetko uključuje pripovijedanje - a tako je i u ovom tekstu, premda je naracija svedena na minimum, na ponavljanje kratke priče o Isusovu čudu kojim pomaže sv. Patriku u pokrštavanju pogana.

\section{PURGATORII I STUDENAC}

Pozornost privlači i jedna zanimljivost u Fatevićevu zborniku koja nas vraća na početak ovoga razmatranja. Naime, izraz purgatorii kadšto se zamjenjuje riječju studenac (u talijanskom predlošku višekratno se rabi izraz pozzo), a to podsjeća na druge srednjovjekovne tekstove u kojima se tematizira »položaj« čistilišta. ${ }^{46}$ Izvještaj viteza Oweina koji je posjetio čistilišnu špilju u Lough Derg na sjeveru Irske ${ }^{47}$ poticaj je shvaćanju, ali - rekla bih - i njegov posljedak, koje je zamjetno već u Grgura Velikoga, da se i na ovoj zemlji, u tuzemnoj, tjelesnoj stvarnosti nalaze čistilišna mjesta u kojima se mogu okajati grijesi. ${ }^{48}$

U 12. stoljeću, otprilike u vrijeme nastanka vizije koja pripovijeda o silasku u Čistilište sv. Patricija, o mukama koje se tamo mogu doživjeti, ali i o radostima koje se naziru, bilo je više žena koje su iskazivale tzv. čistilišnu pobožnost

\footnotetext{
${ }^{44}$ Dakako, ova je dihotomija vrlo reduktivna i uvjetna.

${ }^{45} \mathrm{O}$ upućenosti na širu pastvu mogu, primjerice, svjedočiti i neke propovijedi zapisane u Fatevićevu zborniku, kao i nabožni pripovjedni tekstovi.

${ }^{46}$ Ukratko o teološkim izvorištima nazora o čistilištu usp. SCHEFFCZYK 1999: 327-330.

${ }^{47}$ Hodočašća u taj purgatorij zabranio je papa Aleksandar VI. godine 1497., ali bez potpunoga učinka, jer je tamo sagrađena crkva i bila posjećivana do u 20. stoljeće. To je iznimno svjedočanstvo vjere i očuvanja tradicije. Usp. LE GOFF 1984: 242.

${ }^{48}$ Usp. o tome DENEKE 1999: 330-331.
} 
(purgatorial piety, sintagma Barbare Newman). ${ }^{49}$ Među njima važno mjesto zauzima Hildegarda iz Bingena, osobito njezino već spomenuto vizionarskoteološko djelo Liber vitae meritorum (napisano između 1158. i 1163. godine), jedinstven spoj vizije, prenja, kozmologije i teološko-pastoralnoga djela, s gotovo skolastički razrađenim postupcima pokore za određene prijestupe. ${ }^{50}$ Tamo ona, u sklopu svoje sveobuhvatne slike svijeta kroz sve vrijeme, smješta čistilište u ogromna prostranstva na zemlji: na sjever (tamo se muče bludnici i nevjernici), na jug (mjesto kazne za zločince) i na zapad (tamo se čiste grešnici s lakšim prijestupima). ${ }^{51}$ To je zemaljsko čistilište visokim planinama $i$ dubokim usjecima odvojeno od nastanjenoga i plodnoga dijela zemlje, čime je uopće omogućen život. ${ }^{52}$ Čistilište nije samo za pokojne, ono je i za žive. $\mathrm{Na}$ taj je način Hildegarda iz Bingena upravo doctrix purgatorii (kako je zove B. Newman), a njezino je učenje utjecalo na poimanje čistilišta i u teološkim raspravama, i kod laika (npr. kod begina). Hildegarda opisuje čistilišne prostore, njihov izgled i način na koji se duše u njima muče - uzročno su povezane vrste prijestupa i kazne koje se zbog toga moraju podnijeti. Takve se veze između grijeha i kazne zatječu i u starijim vizijama, ali sporadično: primjerice, u Bogorodičinoj apokalipsi lašci i krivokletnici obješeni su za vlastite jezike, a bludnici do pasa uronjeni u goruću rijeku. Međutim, ni u jednom svom tekstu Hildegarda ne savjetuje ljudima da idu ovamo ili onamo, da hodočaste u neko određeno mjesto; čistit će se od grijeha nakon smrti, a muke se mogu ublažiti pokorom za života (postom, milosrdnim djelima, molitvama, ali i tjelesnim kaznama). Tako primjerice kaže: »qui in seculo penitentiam facientes pleniter non purgantur, corporibus exute penis plenius examinantur «. ${ }^{53}$ Jedini za koje nema spasa su samoubojice, jer »cum quo se ipsum per penitentiam purgare debuit, se totum sine consolatione extinxit. $\ll^{54}$

U našem kontekstu valja osobito istaknuti i Hildegardino medicinsko djelo Causae et curae (napisano oko 1150. g.). Tamo je zapisan i odsječak o nekim mjestima na zemlji - dakle, o geografskoj i geološkoj stvarnosti - u kojima se rasplamsava čistilišna vatra uzrokovana ljudskim grijesima i prijestupima. Ta materijalizirana čistilišna vatra može kažnjavati, pa time i čistiti, grešne duše; s druge strane, od takve vatre nastaju vrući izvori vode koji su ljekoviti jer

\footnotetext{
${ }^{49}$ Usp. BYNUM 1987: 120-123.

${ }^{50}$ O tome v. NEWMAN 1993: 91.

${ }^{51}$ Cjelovit je tekst kritički objavljen u seriji Corpus Christianorum: CARLEVARIS 1995.

${ }^{52}$ I za pakao se u dijelu srednjovjekovne kozmologije smatralo da se može naći (i) na zemlji, kako se čita u prijevodu Lucidara iz Žgombićeva zbornika: "pakal' estь na sem' svete i est' pred' nim' magla i t'ma« (12r).

${ }^{53}$ CARLEVARIS 1995: 65.

${ }^{54}$ CARLEVARIS 1995: 62.
} 
čiste ljudska tjelesa od nezdravih sokova. Tako se međusobno vežu »ovozemaljsko čistilište « i onostrano čistilište, prostor vječnosti za one koji moraju otrpjeti kazne prije nego stignu u raj. ${ }^{55}$ Taj se stav najjasnije iščitava iz 486. odsječka djela Causae et curae, u kojemu piše o neugasivim vatrama koje su uzrokovane ljudskim grijesima i prijestupima, pa tako onda iste te vatre kažnjavaju i kušaju grešnika - kao što se zlato kuša u vatri, tako se i duše kušaju u čistilištu. Nad neke dijelove zemlje takva je »kažnjavajuća« vatra sišla $i$ gorjet će do konca vremena. Ona može zagrijavati rijeke i potoke, a neke od njih ljudi su uspjeli iskoristiti jer su ljekovite, pa se u njima kupaju:

Quidam etiam inextinguibiles ignes in aere sunt, qui de diuersis operibus hominum incendentur, quoniam, qui illis ad gloriam esse debebant, ex malis operibus eorum ipsis ad penales ignes fiunt et ita in aliqua loca terrarum descendunt. Et ibi congregantur, ubi etiam aliqua flumina oriuntur et effluunt, que calorem et ardorem ex eisdem ignibus contrahunt, ita quod etiam iudicio Dei quedam anime in ipsis ignibus et in ipsis aquis examinantur. [...] Et terra et montes et lapides, quos ignis ille tetigit, in igne semper ardebunt usque ad nouissimum diem. [...] qui balneis in eis utuntur, interdum non ledunt, sed eis sanitatem conferunt, qua calor earum iniustum ardorem, qui in illis est, conpescit et malos humores in eis consumit. $^{56}$

Na taj način ona nastoji objasniti termomineralne izvore vode i njihovu korisnost za tijelo; s druge strane, dopušta se mogućnost očišćenja od grijeha već za ovoga života. Neke prirodne pojave Hildegarda dovodi u vezu sa zemaljskim čistilištem, koje je pak odraz, »postvarenje « i predokus onostranoga. A mišljenje da se čistilište može naći i negdje na zemlji iznosi se i u dijalogu iz Fatevićeva zbornika: »esu veĉe purgatoriev i dakle i jistino da i prgatorii od svetoga Patriciê«, odnosno »il Purgatorio (non parlando ordinariamente) si ritroua in più luoghi«.

Na kraju se teksta u Fatevićevu zborniku nakratko, kao neka potvrda, spominje Patrikov prijatelj koji je bio osuđen na »niko mesto na zemli« - to je opet (ovo)zemaljsko čistilište, dakako bez navođenja vrste muke i točne lokacije tih muka. U fra Angelovu tekstu nema povezivanja zemaljskih nedaća (npr. tuče, poplave, vatrene pošasti) i čistilišta koje je planinom odvojeno od ljudi, kao što piše Hildegarda. Ona u svojim opsežnim, maštovitim i teološki

\footnotetext{
$55 »$ The Purgatory of the dead, though separated from the land of the living, is nevertheless in contact with it and contributes to punitive and purgatorial conditions on earth « (NEWMAN 1993: 94). O stranama svijeta gdje se nalaze oni koji se muče čita se već i u starim, apokrifnim vizijama - tako i Pavlova vizija opisuje teže muke za grešnike na zapadnoj strani (»i vzeše me paki na zapadb«, »na zapadb sl'nca«), a u Bogorodičinoj apokalipsi arkanđeo Mihael vodi Bogorodicu prvo »na polud'ne« a zatim »na zapadь«.

${ }^{56}$ Cit. prema kritičkom izdanju MOULINIER 2003: 282.
} 
razrađenim vizijama (koje su uvijek vrlo individualan spoj viđenja, teološke rasprave i pastoralne pouke) nikad ne opisuje pakao i raj, samo piše o njima - po njezinu shvaćanju, uzvišeno blaženstvo raja i užas vječne kazne ne mogu se ni vidjeti, a kamoli ljudskim jezikom dočarati. Čistilište je pak moguće barem djelomično opisati, odnosno prispodobiti slikama iz života i prirode. Povezanost zemaljskoga i vječnoga čistilišnog ognja, kako smo pokazali, u njezinu opusu potaknuta je stalnim nastojanjem oko iskazivanja bitnoga jedinstva kozmosa i čovjeka - transcendentnoga i vremenitoga, duše, duha i tijela, zdravlja i bolesti, dobra i zla, a to stalno međuprožimanje uzrokuje razne pojave u tvarnom svijetu i u vječnosti. ${ }^{57}$

\section{ZAKLJUČAK}

Ideja o čistilištu kao zasebnom mjestu i stanju u kojem se muče duše koje nisu ni sasvim zle ni sasvim dobre na kršćanskom se Zapadu konačno oblikuje tijekom 12. stoljeća, pa se može pretpostaviti da je Tractatus de Purgatorio Sancti Patritii (i njegovi prijevodi) imao i funkciju da »prevede« vjersku doktrinu u dramatično, maštovito pripovjedno djelo, u događaje i likove. S druge strane, u vrijeme sastavljanja Zarcala i njegova izvornika ta je doktrina u katoličkom svijetu već bila prihvaćena; stoga u okviru poučnoga teksta ilustracije bivaju svedene na minimum. Razvedeniji je tek uvodni dio, koji tumači kako je irsko čistilište uopće nastalo. Tu se zatječe hagiografski diskurs, odnosno njegov odraz koji ustupa mjesto poučnom diskursu - zato se i ishodišno čudo, Isusov zahvat, zatim priča o tome što pokajnici u zemaljskom čistilištu vide, iskazuje sažeto, u obliku koji odgovara nadređenom kontekstu moralnopoučnoga djela.

Lokus i fenomen Čistilišta sv. Patricija traje kroz stoljeća, pa i hodočašće u taj kraj i njegovi tekstualni spomeni, bilo u književnim bilo u poučnim sastavima. To je dakle jedinstven fenomen u europskoj kulturnoj povijesti, pa i povijesti (katoličke) pobožnosti. No nazori o mogućnosti postojanja »ovozemaljskoga« čistilišta nalaze se i u drugih autora, od sv. Grgura Velikog do sv. Hildegarde, pa i dalje do u 18. stoljeće - uostalom, katkad se i vulkan Etna doživljavao kao postvarenje Božjega gnjeva. Osim toga, ne čudi što je u popularnoj pobožnosti, koja je od srednjega vijeka hranjena više slikama muka nego li obećanjima radosti, bila privlačna mogućnost okajanja grijeha već za života, i smanjivanja patnje nakon smrti. Dakle, u poučnom tekstu naglasak

\footnotetext{
$\overline{57}$ »Wechselspiel von Mensch und Welt, die Zusammenhänge der seelischen Konstitution des Menschen, die heilsgeschichtliche Durchdringung der Schöpfung und den Hinweischarakter der sinnlich wahrnembaren Welt auf die göttlichen Geheimnisse.« (ZÁTONYI 2014: 32).
} 
nije na zastrašivanju mukama, na živopisnu opisivanju đavala i njihovih oruđa, već je naglasak na tome da se duše purgivâu već za života jer je pravo vrijeme i mjesto za pokajanje ovdje i sada - ali naglasak može biti i na jačanju povezanosti zajednice živih i zajednice pokojnika. Zastrašivanje u poučnom tekstu nije toliko prisutno, naglasak je na nadi jer, koliko god muke bile strašne, govor o čistilištu uvijek nudi više utjehe od straha. Međutim, nebrojene su propovijedi i egzempli koji naglašavaju upravo strahotu muka u čistilištu, koje je valjalo nastojati izbjeći pokorom za života i ispravljanjem ponašanja.

Možda je zanimanje za ovozemaljsko čistilište barem dijelom povezano sa specifičnim kasnosrednjovjekovnim materijalizmom. ${ }^{58}$ Među takvim »dostupnim « čistilištima vjerojatno je najpoznatiji očistac' (kako stoji zapisano u Oxfordskom zborniku) bilo upravo Čistilište sv. Patricija, a hodočašće u nj bilo je izraz konkretne pokorničke pobožnosti. Dakle, tekst u Fatevićevu zborniku može biti primjerom kako se neki pogledi, nazori i vjerovanja nisu širili iz teoloških rasprava u puk, već je kretanje moglo biti i obratno - od tradicionalne pobožnosti prema poučnim djelima. Zarcalo duhovno, uz druge pouke o čistilištu i vječnosti, o časovima umiranja i načinu bene moriendi sadrži kao »ravnopravan« odsječak o Čistilištu sv. Patricija, u kojemu neki mogu oprati ljagu grijeha - doduše, tko i kako to može učiniti nije podrobno objašnjeno. No to je ipak pokazatelj kako je u 12. stoljeću učinjen važan korak prema individualizaciji, prema osobnoj odluci i osobnoj pokori. U kontekstu poučnoga teksta namjerno su izostavljeni dramatični opisi prostora i stanja mučenja - vizualizacija tih stanja pripadala bi više domeni redovničke meditacije, ili bi slikoviti opisi oživljavali sadržaj za laičku publiku u okviru eshatološke vizije, dakle narativnoga djela. U promatranom se tekstu navodi da su neki ljudi doživjeli pokoru i očišćenje, ne samo kao »dokaz« iznimnosti toga mjesta i mogućnosti spiranja grijeha, nego i stoga što se držalo da se općenito bolje razumije ono što je netko iskusio, doživio pa dakle iskustveno shvatio. Adresat Fatevićeva teksta trebao se zadovoljiti time što je kazano, ponovit ćemo: »ovo dosti budi za sada«. Tu se spajaju tumačenje, znanje, vjerovanje i silentium. Silazak u čistilište sv. Patricija u Zarcalu je prikazan više kao vrsta ljudskoga »sudjelovanja« s Bogom; nekakva »osobna iskustva« spominju se samo u vezi s autoritetima (npr. sa sv. Bonaventurom i Antoninom ${ }^{59}$ ) kako bi im se pridala veća težina, ali ne i istinitost sama po sebi. ${ }^{60}$ Uostalom, već je

${ }^{58}$ Pritom ne mislimo na filozofski materijalizam Blazija iz Parme (Biagio Pelacani, 14. st.) i drugih mislilaca.

${ }^{59} \mathrm{U}$ hrvatskoglagoljskom tekstu umjesto sv. Antonina spominje se sv. Anton.

${ }^{60}$ Tijekom kasnoga srednjeg vijeka već je započela rasprava o doživljajima koji su nazivani viđenjima, o ulozi mašte u takvim doživljajima i uopće o mogućnostima i granicama ljudskoga odnosa prema božanskome. O naravi vizija raspravljali su teolozi od Augustina do 
Beda Časni viziju držao znakom koji pokazuje istinu, a ne (nužno) istinom po sebi ili kakvim dokazom.

Ovom je analizom pokazano kako su u hrvatskoglagoljskoj tradiciji zabilježena $d v a$ teksta koja tematiziraju Čistilište svetoga Patricija: jedan je vizija (sačuvana u Oxfordskom zborniku iz 15. stoljeća), a drugi je poučni/teološki traktat (zapisan u Fatevićevu zborniku s početka 17. stoljeća). Među njima postoje znatne razlike, a ono što ih povezuje jest činjenica da oba teksta izviru iz legende o Patricijevu čudu sa zemaljskim čistilištem, a koje se prvi put spominje u 12. stoljeću. Zanimanje za tu vrstu eshatoloških vizija kao doživljaja, putovanja kroz prostore muka ili rajskoga užitka, pa tako i za literaturu vizija postupno je izblijedjelo - u hrvatskoglagoljskoj književnosti koja je većim dijelom praktičnoga značaja takve se vizije prepisuju do 16. stoljeća (npr. u Grškovićevu zborniku, ali tu je riječ o apokrifima). Međutim, nedvojbeno je da postojanje književnoga sastava o ovozemaljskom čistilištu, kao i spominjanje čistilišta sv. Patrika u kontekstu teološkoga djela pokazuje stoljetno prožimanje teološke doktrine i pučke pobožnosti - ne nužno tim redoslijedom. Poučni tekst u Fatevićevu zborniku, dio opsežnoga Zarcala duhovnoga, tumači da se i iz raznih liendi i iz ištorie može mnogo naučiti o ispravnom životu, o pokori i nadi u vječni spas.

\section{IZVORI}

SPECCHIO SPIRITVALE Del principio, e fine della Vita humana [...] Per il R. P. F. Angelo Elli da Milano, Minor Osseruante [...] In Treuiso, Appresso Fabritio Zanetti, M. DCI.

Fatevićev zbornik duhovnoga štiva, 1617. g., Zagreb, Arhiv Hrvatske akademije znanosti i umjetnosti, sign. $I V$ a 124 .

Oxfordski zbornik, 15. st., Oxford, Bodleian Library, sign. Ms. Canon. Lit. 414.

Petrisov zbornik, 1468. g. Zagreb, Nacionalna i sveučilišna knjižnica, sign. $R 4001$.

Z̆gombićev zbornik, 16. st., Zagreb, Arhiv Hrvatske akademije znanosti i umjetnosti, sign. VII 30.

\section{LITERATURA}

BYNUM, C. W. 1987. Holy Feast and Holy Fast: The Religious Importance of Food to Medieval Women. Berkeley: University of California Press.

Bonaventure, te učenjaci kao Robert Grosseteste i Roger Bacon. Te su rasprave naizgled upravljene samo učenima; manje obrazovan puk ostao je na neki način vjeran takvoj vrsti tekstova tijekom stoljeća. 
CARLEVARIS, A. (prir.) 1995. Hildegardis Liber vite meritorvm (= Corpus Christianorum Continuatio Mediaeualis XC). Turnhout: Brepols.

CARRUTHERS, M. 1998. The Craft of Thought. Meditation, Rhetoric and the Making of Images 400-1200. Cambridge: Cambridge University Press.

CHIETTINI, E. 1948. Angelo da Milano. Enciclopedia cattolica I. Città del Vaticano: Ente per l'Enciclopedia Cattolica e per il Libro Cattolico, 1257.

CRÓINÍN, D. Ó. 1998. Patrick (Patrizius). Lexikon des Mittelalters Bd. VI. Stuttgart Weimar: Metzler Verlag, 1791-1792.

DELIMO, Ž. (Jean Delumeau) 1986. Greh i strah. Stvaranje osećanja krivice na Zapadu od XIV do XVIII veka (prev. Z. Stojanović). Novi Sad: Književna zajednica Novog Sada - Dnevnik.

DENEKE, B. 1999. Fegefeuer, Volksglauben. Lexikon des Mittelalters, Bd. IV. Stuttgart Weimar: Verlag J. B. Metzler, 330-331.

DINZELBACHER, P. 1991. »Revelationes" (=Typologie des sources du Moyen Âge occidental, fasc. 57). Turnhout: Brepols.

DUFFY, E. 1992. The Stripping of the Altars. Traditional Religion in England 1400-1580. New Haven - London: Yale University Press.

DÜRRIGL, M.-A. (prir.). 2013. Hrvatska srednjovjekovna proza II: Apokrifi, vizije, prenja, Marijini mirakuli. Zagreb: Matica hrvatska.

DÜRRIGL, M.-A. 2016. Eshatološke vizije u hrvatskoglagoljskoj književnosti. Žanrovske i poetičke značajke. Zagreb: Hrvatska sveučilišna naklada.

EASTING, R. 1986. Owein at St Patrick's Purgatory. Medium Aevum 55: 139-157.

FRANOV-ŽIVKOVIĆ, G. 2016. Fatevićev zbornik duhovnog štiva. B. Bančuga, J. Faričić, P. Kero (ur.). Riznica glagoljaške kulture i hrvatske pismenosti otoka Rave, sv. 3. Fatevićev zbornik duhovnog štiva 1617. Zadar: Stalna izložba crkvene umjetnosti - Sveučilište u Zadru, 7-12.

GATCH, M. M. 1991. Perceptions of Eternity. M. Godden, M. Lapidge (ur.). The Cambridge Companion to Old English Literature. Cambridge: Cambridge Univesity Press.

GRABES, H. 1982. The mutable glass. Mirror-imagery in titles and texts of the Middle Ages and the English Renaissance (transl. G. Collier). Cambridge - London - New York - New Rochelle - Melbourne - Sydney: Cambridge University Press.

GREGUREK, R. 2011. Psihološka medicina. Zagreb: Medicinska naklada.

IVŠIĆ, S. 1948. »Čistilište sv. Patricija« u hrvatskom glagoljskom tekstu. Starine JAZU 41: 111-118.

JACOBUS da VORAGINE. 2014. Zlatna legenda, sv. I (prev. S. Pavić). Zagreb: Demetra.

LE GOFF, J. 1984. Die Geburt des Fegefeuers (Übers. A. Forkel). Stuttgart: Klett Cotta.

LE GOFF, J. 1988. Your Money or Your Life. Economy and Religion in the Middle Ages (transl. P. Ranum). New York: Zone Books.

LUCIĆ, P. 1990. Vartal (prir. N. Kolumbić). Split: Književni krug.

MOULINIER, L. (prir.). 2003. Beate Hildegardis Cause et cure. Berlin: Akademie Verlag. 
NEWMAN, B. 1993. Hildegard of Bingen and the »Birth of Purgatory«. Mystics Quarterly XIX/3: 90-97.

PETROVIĆ, I. 1998. Fatević, Mikula. T. Macan (gl. ur.). Hrvatski biografski leksikon, sv. 4. Zagreb: Leksikografski zavod »Miroslav Krleža«, 143.

RADOŠEVIĆ, A. 2012. Korizmene propovijedi u Fatevićevu zborniku - prilog rekonstrukciji glagoljskoga Korizmenjaka. Slovo 62: 101-210.

SCHEFFCZYK, L. 1999. Fegefeuer, Biblisch-theologisch. Lexikon des Mittelalters, Bd. $I V$. Stuttgart - Weimar: Verlag J. B. Metzler, 329-330.

SPILLING, H. 1975. Die Visio Tnugdali. Eigenart und Stellung in der mittelalterlichen Visionsliteratur bis zum Ende des 12. Jahrhunderts. München: Arbeo Gesellschaft.

ŠTEFANIĆ, V. i sur. 1969. Hrvatska književnost srednjega vijeka od XII. do XVI. stoljeća. Pet stoljeća hrvatske književnosti knj. I. Zagreb: Zora - Matica hrvatska.

ŠTEFANIĆ, V. 1970. Glagoljski rukopisi Jugoslavenske akademije II. Zagreb: Jugoslavenska akademija znanosti i umjetnosti.

THIÉBAUX, M. 1994. The Writings of Medieval Women. An Anthology. London - New York: Routledge.

WADDINGUS, L. 1806. Scriptores Ordinis Minorum: Quibis accessit syllabus illorum qui ex eodem ordine pro fide Christi fortiter occubuerunt. Romae: Ex Typographia S. Michaelis ad Ripam.

ZÁTONYI, M. (prir. i prev.). 2014. Einleitung. Hildegard von Bingen. Das Buch der Lebensverdienste - Liber vitae meritorum. Rüdesheim/Eibingen - Beuron: Beuroner Kunstverlag, 8-36.

\section{Summary \\ Marija-Ana Dürrigl \\ INSTRUCTION ON EARTHLY PURGATORY IN THE FATEVIĆ MISCELLANY}

The Fatevic Miscellany from 1617 contains the moral didactic composition Zarcalo duhovno. That is the translation of the work Speculum spiritale, one section of which is dedicated to St. Patrick's Purgatory. The existence of an earthly purgatory came about as a consequence of contemplations about purgatory as an »intermediate« place in eternity. The specific views of Hildegard of Bingen about the interconnection of the transcendental and the material world have to be pointed out in this context. The most popular topographic point in which the eternal joined with the temporal was thought to be St. Patrick's Purgatory in the north of Ireland. It was described in numerous sources as the destination of penitent pilgrimage, as well as a place in which souls are tormented or (far less often) experience beatitude. That location is the theme of two Croatian Glagolitic texts: a narrative, literary text (eschatological vision) in the Oxford Miscellany, and the theological, didactic segment in the younger Fatevic Miscellany. This shift may indicate that literary taste changed over time, and that in the early 17 th century such subjects were less appealing to a literary audience, whereas it was still engaging for the recipients of theological works. In the Fatevic Miscellany the moral on earthly purgatory is part of con- 
siderations on the art of living and dying well. The dramatic and poetic vision from the Oxford Miscellany has already been studied, while the moral-didactic text, which is published in this paper in Latin transliteration, is less well known. Since the main purpose of Zarcalo duhovno is edification, its aesthetic qualities are minimal. The studied text about St. Patrick's Purgatory reflects the connection between theological doctrine and lay piety.

Keywords: Fatević Miscellany, Croatian Glagolitic moral-didactic prose, visions, St. Patrick's Purgatory, Hildegard of Bingen 